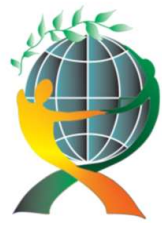

\author{
(online) $=$ ISSN $2285-3642$ \\ ISSN-L = $2285-3642$ \\ Journal of Economic Development, Environment and People \\ Volume 8, Issue 3, 2019
}

URL: http://jedep.spiruharet.ro

e-mail: office jedep@spiruharet.ro

\title{
The Effect of Perception on the Benefits of Tax toward the Discipline of Paying Taxes in Jakarta
}

\author{
Wening Estiningsih ${ }^{1}$, Juni Mashita ${ }^{1}$, Sidik Lestiyono ${ }^{2}$ \\ ${ }^{1}$ Indraprasta PGRI University, Jakarta-Indonesia \\ ${ }^{2}$ Gunadarma University, Jakarta-Indonesia
}

\begin{abstract}
Perception of the benefits received by the community as compensation for paying taxes is one of the factors that influence the discipline of society in paying taxes. Thus the purpose of this study is to examine more deeply the effect of perceptions on the benefits received from paying taxes on discipline in paying taxes in Jakarta. The population in this study was individual taxpayers who work as lecturers on two campuses located in Jakarta. The number of respondents involved in the study was 56 people. The analysis method used is descriptive statistics. The results of the study show that the perception of the benefits of paying taxes will affect the willingness of the community (especially taxpayers) to pay taxes on time. So that in increasing the discipline of society, especially taxpayers, the Government needs to provide concrete examples of development that directly impact and can be felt by the community.
\end{abstract}

Keywords: Tax, perception, discipline, Jakarta

JEL Codes: A01

How to cite: ESTININGSIH, W., MASHITA, J., \& LESTIYONO, S. (2019). The Effect of Perception on the Benefits of Tax toward the Discipline of Paying Taxes in Jakarta. Journal of Economic Development, Environment and People, 8(3), 16-21 doi:http://dx.doi.org/10.26458/jedep.v8i3.632

\section{Introduction}

Tax is one of the sources of state revenue that has an important role in supporting development finance and illustrating economic independence (Meuwissen and Quick, 2019). On State Revenue and Expenditure, it is known that tax is one of the main components of State revenue (Simanjuntak and Mukhlis, 2012). For the country, taxes are the largest source of state revenue where state revenues from the taxation sector account for almost $80 \%$ of total state revenues (Supramono and Damayanti, 2010).

Compliance with paying taxes becomes a problem related to tax issues in Indonesia. Tax compliance is a taxpayer willing to carry out its obligations without any coercion in paying taxes based on regulations that are still valid (Trisnawati and Sudirman, 2015). Compliance with taxpayers can be said as compliance with reporting requirements where taxpayers submit, report and pay their obligations in accordance with 


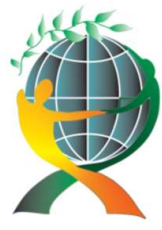

\author{
(online) $=$ ISSN $2285-3642$ \\ ISSN-L = $2285-3642$ \\ Journal of Economic Development, Environment and People \\ Volume 8, Issue 3, 2019 \\ URL: http://jedep.spiruharet.ro \\ e-mail: office jedep@spiruharet.ro
}

applicable regulations (Devos, 2009). Compliance of taxpayers to fulfil their tax obligations needs to be increased in order to create the desired tax target (Doran, 2009).

People or taxpayers who are aware of making tax payments will improve the welfare of the community indicating that they want to participate in supporting the country's development (Tatiana and Hari, 2009; Untari et al, 2017). However, it does not rule out the possibility that the awareness of taxpayers to pay taxes is getting lower by delaying tax payments and reducing tax burdens, causing State revenues to tax to decline (Nalendro and Isgiyart, 2014)

Knowledge of tax regulations is important to foster obedient behaviour because of how taxpayers may be ordered to comply if they do not know how the tax regulations (Untari, 2016). In addition to knowledge about tax regulations, perceptions of the benefits received by the community as compensation for tax payments are one of the factors that influence the discipline of the public in paying Widayati and Nurlis taxes (2010).

Since the issuance of Law No. 6 of 1983, which was later amended by Law No. 28 of 2007 concerning General Provisions and Procedures for Taxation (KUP) known as the Self Assessment System that gives trust to taxpayers to calculate, pay, and report their own tax payable. To realize voluntary compliance, optimal functions are needed such as tax dissemination, tax services and tax enforcement. With the adoption of the Self Assessment System, in addition to relying on taxpayers' awareness and honesty, adequate tax technical knowledge also plays an important role, so that taxpayers can carry out their tax obligations properly and correctly. Because through this system, every taxpayer is obliged to fill in himself and submit an Annual Announcement Letter (SPT) correctly, completely, and clearly (Nalendro and Isgiyart, 2014). Based on this background, it is important for researchers to examine more deeply the influence of perceptions on the benefits received from paying taxes on discipline in paying taxes in Jakarta.

\title{
2. Taxes in Economic Development
}

Tax is a means of equalizing the income of citizens and the source of state development funds for the government. So in the long run the general public can enjoy the effects of this development (Aladejebi, 2018). For example, if you pay highway tax, you will enjoy the benefits of repairing highways in your area. Based on Article 1 number 1 Law No. 6 of 1983 which was then refined with Law No. 28 of 2007 concerning general provisions and tax procedures. Tax is "compulsory contribution to the state owed by an individual or entity that is compelling based on the Law, with no direct reciprocity and used for the state's needs for the greatest prosperity of the people"

So in addition to reciprocal services that are indirect, tax collection is based on legal norms and is forced so that refusal to pay taxes or avoid them generally includes violations of law (Adigamov and Tufetulov, 2014). Therefore, every citizen must pay taxes according to the rules. Tax has a very important role in the life of the state, especially in the implementation of development because tax is a source of state income to finance all expenses including development expenditure. Please check the various tax functions in the description below.

As a source of state income, taxes function to finance state expenditures. To carry out the routine tasks of the state and carry out development, the state needs money. This fee can be obtained from tax revenue. Today taxes are used for routine financing such as employee expenditure, goods shopping, maintenance, 


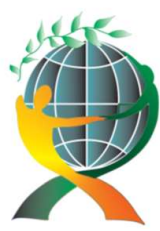

\author{
(online) $=$ ISSN $2285-3642$ \\ ISSN-L = $2285-3642$ \\ Journal of Economic Development, Environment and People \\ Volume 8, Issue 3, 2019 \\ URL: http://jedep.spiruharet.ro \\ e-mail: office jedep@spiruharet.ro
}

and so forth. For development financing, money is spent on government savings, namely domestic revenues minus routine expenses. This government savings from year to year must be increased according to the increasing financing needs of development and this is mainly expected from the tax sector.

Regulating Function (Regular). The government can regulate economic growth through tax policy. With regulating functions, taxes can be used as a tool to achieve goals. For example, in order to bring investment, both domestically and abroad, various types of tax relief facilities are provided. In order to protect domestic production, the government sets a high import duty for foreign products.

Stability Function. With taxes, the government has the funds to carry out policies related to price stability so that inflation can be controlled, this can be done, among others, by regulating the circulation of money in the community, tax collection, effective and efficient use of taxes.

Revenue Redistribution Function. The tax that has been collected by the state will be used to finance all public interests, including also financing development so that it can open employment opportunities, which in turn will increase people's income.

\title{
3. Methodology
}

The population in this study were individual taxpayers who work as lecturers on two campuses located in Jakarta. The number of respondents involved in the study was 56 people. In this study Cross-Sectional Design is used, where information collection from each element of the sample population is carried out only once at a certain time. Then, the researcher conducted a survey, namely a research design that collected data from a number of sample respondents selected from a population. Data was collected using a questionnaire instrument. The questionnaire is structured. At the time of the survey, the sampling technique was carried out by convenience sampling.

The analysis method used is descriptive statistics, descriptive analysis techniques are used to analyze data by describing or describing data that has been collected as it is without the intention to make conclusions that apply to the general or generalization. Inferential Statistics with a statistical model $\mathrm{Y}=\mathrm{a}+$ $b X+e$, this technique uses inferential analysis to explain the results of the study. With $t$ test aims to test the regression coefficient. Welcome to JEDEP, Issue nr.1. The journal's coverage is : general economics, sustainable development, eco-development, distribution of wealth, household behaviour and family economics, human resources, incomes distribution, human development, migration, business management, marketing, consumer behaviour It also provides a friendly platform for academic and application professionals from crossing fields to communication together.

\section{Result}

In the perception variable, the statement used is 7 statements, recapitulation of questionnaire calculations on the $\mathrm{X}$ variable in Table 1.

Based on the recapitulation data, it can be seen that the majority of respondents' perceptions of the benefits received from paying taxes are positive; $22.56 \%$ in the hesitation category, $21.30 \%$ in the agree category and 24.31 in the category strongly agree. In the discipline variable, the statement used is 5 statements, recapitulation of questionnaire calculations on the $Y$ variable in Table 2. 


$$
\begin{gathered}
\text { (online) }=\text { ISSN } 2285-3642 \\
\text { ISSN-L }=2285-3642
\end{gathered}
$$

\section{Journal of Economic Development, Environment and People}

Volume 8, Issue 3, 2019

URL: http://jedep.spiruharet.ro

e-mail: office jedep@spiruharet.ro

\begin{tabular}{|c|c|c|c|c|c|}
\hline Questions & 1 & 2 & 3 & 4 & 5 \\
\hline$x 1$ & 7 & 6 & 11 & 17 & 16 \\
\hline$x 2$ & 10 & 7 & 7 & 15 & 18 \\
\hline$\overline{x 3}$ & 5 & $\overline{16}$ & $\overline{13}$ & $\overline{11}$ & $\overline{12}$ \\
\hline $\mathrm{X} 4$ & 9 & 13 & 21 & 9 & 5 \\
\hline$\times 5$ & 3 & 11 & 11 & 15 & 17 \\
\hline$x 6$ & 6 & 12 & 11 & 11 & 17 \\
\hline$x 7$ & 9 & $\overline{13}$ & 16 & 7 & 12 \\
\hline Total & 49 & 78 & 90 & 85 & 97 \\
\hline Percent & 12,28 & 19,55 & 22,56 & 21,30 & 24,31 \\
\hline
\end{tabular}

Table 1. Recapitulation of Variable $X$

Resource : Data processed, 2019

\begin{tabular}{|c|c|c|c|c|c|}
\hline Questions & 1 & 2 & 3 & 4 & 5 \\
\hline $\mathrm{x} 1$ & 11 & 8 & 10 & 11 & 17 \\
\hline$x 2$ & 5 & $\overline{11}$ & 7 & 15 & 19 \\
\hline $\mathrm{x} 3$ & 7 & 11 & 11 & 16 & 12 \\
\hline $\mathrm{X} 4$ & 3 & 14 & 16 & 5 & 19 \\
\hline$\overline{x 5}$ & $\overline{5}$ & $\overline{12}$ & $\overline{9}$ & $\overline{13}$ & $\overline{18}$ \\
\hline Total & 31 & 56 & 53 & 60 & 85 \\
\hline Percent & 10,88 & 19,65 & 18,60 & 21,03 & 29,82 \\
\hline
\end{tabular}

Table 2. Recapitulation of Variable $Y$

Resource: Data processed, 2019

Similar to the results of the perception variable, respondents' assessment of discipline in paying majority tax is positive; $21.05 \%$ in the agree category and 29.82 in the category strongly agree. Based on data processing, obtained a simple regression equation with a regression equation: $Y=1.127+0.643 X$, where $a=1.127$ is a constant, explaining that if Perception on benefits obtained from tax payments $(X)$ is 0 then the discipline of paying $\operatorname{tax}(Y)$ is equal to 1,127 . While the regression coefficient $b=0.643$ states that every increase in variable $X$ is equal to 1 unit, it will be able to increase the $Y$ variable by 0.643 . So that in increasing the discipline of society, especially taxpayers, the Government needs to provide concrete examples of development that directly impact and can be felt by the community.

Validity test is used to test the extent to which the accuracy of a measuring instrument can reveal the concept of a measured phenomenon / event. The test results show that all indicators used to measure all variables in this study are stated as valid items. That is obtained from the variable indicators used in this study has a correlation value or $r$ count which is greater than $r$ table which is equal to 0.294 for a sample of 57. And in the Reliability test, all item questions have a Cronbach Alpha coefficient greater than 0,60 so that it can be said that all measuring concepts of the variables used in this study are reliable. 


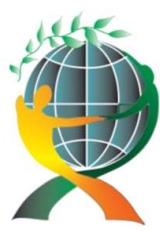

\author{
(online) $=$ ISSN $2285-3642$ \\ ISSN-L = $2285-3642$ \\ Journal of Economic Development, Environment and People \\ Volume 8, Issue 3, 2019 \\ URL: http://jedep.spiruharet.ro \\ e-mail: office jedep@spiruharet.ro
}

Partial Test ( $t$ test) The results of partial tests ( $t$ test) explain that the effect of perception on discipline is indicated by the value of $t$ count of 16.017 with a significance value of $0.000<\alpha=0.05$, so there is a significant influence between the perception of the benefits of tax payments to discipline in paying taxes. From the results of data processing obtained the value of $\mathrm{R}$ is equal to 0.875 or $87.5 \%$ indicating that the correlation / relationship between perception and discipline is very strong because the magnitude $>0.80$, while the coefficient of determination ( $R$ Square) is 0.724 or $72.4 \%$, means that the variation of the perception variable towards the discipline variable is $73.3 \%$, while the remaining $26.7 \%$ is influenced by other variables not examined in this study.

\title{
5. Conclusion
}

Based on the results of the study it can be concluded that the perception of the benefits of paying taxes will affect the willingness of the community (especially taxpayers) to pay taxes on time. Often development is uneven and the Government's slow response to public complaints regarding infrastructure development will degrade the willingness of the community to pay taxes on time. Thus the Government needs to provide concrete examples of development that directly impact and can be felt by the community and improve the response to complaints related to infrastructure and development

\section{References}

[1] Aladejebi,O. 2018. Measuring Tax Compliance among Small and Medium Enterprises in Nigeria. International Journal of Accounting and Taxation December 2018, 6(2): 29-40

[2] Adigamov, F.F and Tufetulov, A.M. 2014. Training of Tax Consultant: Experience and Prospects. Procidea-Social and Behavioural Sciences. 152: 1133-1136

[3] Devos, Ken. 2009. An Investigation into Australian Personal Tax Evaders Their Attitudes towards Compliance and the Penalties For Non Compliance Revenue Low Journal. Vol.19: 149-155

[4] Doran, Michael. 2009. Tax Penalties and Tax Compliance. Harvard Journal On Legislation Vol.46, page: 111-116

[5] Meuwissen, R. Quick, R. 2019. The effects of non-audit services on auditor independence: An experimental investigation of supervisory board members' perceptions. Journal of International Accounting, Auditing and Taxation, 1(4): 2021-2043.

[6] Nalendro, T,I. Isgiyart. 2014. Faktor-faktor yang mempengaruhi keputusan membayar pajak Wajib Pajak Orang Pribadi Yang Berwirausaha Dengan Lingkungan Sebagai Variable Moderasi (Studi Empiris di KPP Pratama Kudus). DIPONEGORO JOURNAL OF ACCOUNTING 3(3): 1-15

[7] Simanjuntak, Timbul H dan Imam Mukhlis. 2012. Dimensi Ekonomi Perpajakan dalam Pembangunan ekonomi. Jakarta: Raih Asa Sukses.

[8] Supramono, Damayanti. 2010. Perpajakan Indonesia. Yogyakarta: CV ANDI

[9] Trisnawati, M. Sudirman, W. 2015. Analisis Faktor-Faktor Yang mempengaruhi Kepatuhan Wajib pajak membayar Pajak Hotel, Pajak Restoran dan Pajak Hiburan Di Kota Demnpasar. E-Jurnal Ekonomi dan Bisnis Universitas Udayana 4(12) : 975-1000

[10] Tatiana, Vanessa Rantung dan Priyo Hari. 2009. “Dampak Program Sunset Policy Terhadap Faktor-Faktor Yang Mempengaruhi Kemauan Untuk Membayar Pajak". Proceeding Simposium Nasional XI. Pontianak 


\author{
(online) $=$ ISSN $2285-3642$ \\ ISSN-L = 2285 - 3642 \\ Journal of Economic Development, Environment and People \\ Volume 8, Issue 3, 2019 \\ URL: http://jedep.spiruharet.ro \\ e-mail: office jedep@spiruharet.ro
}

[11] Untari, DT. 2016. The Potential Development of Betawi Culinary as an Ecotourism Product in Jakarta. Binus Business Review. 7(3), 277-282.

[12] Untari, Dhian Tyas. Avenzora, Ricky. Darusman, Dudung. Prihatno, Joko. 2017. Betawi Traditional Cuisines; Reflection the Native Culture of Jakarta (Formerly Known as Batavia). Journal of Economic Development Environment and People. 6(4), 64-76

[13] Widayati dan Nurlis. 2010. “Faktor-Faktor Yang Mempengaruhi Untuk Membayar Pajak Wajib Pajak Orang Pribadi Yang Melakukan Pekerjaan Bebas Studi Kasus Pada KPP Pratama Gambir Tiga”. Proceeding Simposium Nasional Akuntansi XII. Purwokerto. 